\begin{tabular}{lrr}
\hline Volume 20 & Nomor 1, Januari 2019 & Halaman 26-32 \\
URL: https://jurnal.unej.ac.id/index.php/SEMIOTIKA/index & E-ISSN: 2599-3429 & P-ISSN: 1411-5948
\end{tabular}

\title{
GENDER STRUGGLE IN DEBORAH ELLIS' PARVANA MUD CITY
}

\section{PERJUANGAN GENDER DALAM NOVEL PARVANA MUD CITY KARYA DEBORAH ELLIS}

\author{
Zaindy Roby Hilaldo ${ }^{1}$, Eko Suwargono ${ }^{2}$, L. Dyah PurwitaWardani ${ }^{3 *}$ \\ ${ }^{1}$ Alumni of Faculty of Humanities, Universitas Jember \\ ${ }^{2,3}$ Faculty of Humanities, Universitas Jember \\ *Corresponding Author: dyahpw.sastra@unej.ac.id \\ Informasi Artikel:
}

Dikirim: 5/9/2018; Direvisi: 3/10/2018; Diterima: 2/12/2018

\begin{abstract}
This article dicusses the gender struggle of Shauzia in Mud City by Ellis. The struggle implies the gender condition and critical point of view of the author based on the theory of representation and gender oppression. The representation theory based on Stuart Hall helps to uncover the dominating cultural codes which oppress Shauzia as a person while the gender theory contributes to analyze the layer of dominationin the level of individual, interactional and institutional. This study results in several findings as:the cultural codes represented in the novel are giving benefit the man by the power of military and powerful patriarchy where Shauzia finds hard to go out from camp and work as woman. Furthermore, gender theory plays on scrutinizing the idea as individual woman lacks of rights, and influence her interactional competence as well to stay inside the compound. The institutional system determines her exixtence only to accept what the compound has given to her and not more. Thus she is rejected when she wants to go to France. Ellis poses her self to tell the reader that the value of women in Afganistan at war is unworthy compare to what happens in Europe.
\end{abstract}

Keywords: Afganistan, cultural codes, gender oppression, Mud City, representation

\begin{abstract}
Abstrak
Artikel ini membahas perjuangan Shauzia di dalam novel Mud City. Perjuangan tersebut selain menggambarkan opresi gender juga menunjukkan kecenderungan pengarang berdasarkan pada teori representasi dan kekerasan gender. Teori representasi dimanfaatkan untuk membongkar kode kultural yang mendominasi Shauzia dan teori gender membantu menunjukkan dominasi pada level individual, interaksional, dan institusional. Kajian ini menghasilkan temuan bahwa kode kultural di dalam novel memberikan keuntungan pada laki-laki melalui kuasa militer dan patriarki yang kuat, bahwa Shauzia akhirnya sangat sulit untuk keluar dari pengungsian bahkan dia harus mengubah tampilannya menjadi laki-laki. Dengan teori gender ditemukan bahwa perempuan tidak punya hak mempengaruhi interaksi sosial, sehingga ia hanya berkutat di dalam tempat pengungsian. Pada level institusional, Shauzia hanya bisa beraktivitas di dalam kamp dan tidak dapat pergi ke Perancis. Ellis berupaya untuk menggugah pembaca bahwa keadaan perempuan Afghanistan pada masa perang teramat buruk jika dibandingkan dengan yang ada di dunia luar, yaitu Eropa.
\end{abstract}

Kata kunci: Afghanistan, kode kultural, penindasan, Mud City, representasi 


\section{INTRODUCTION}

Parvana Mud City (2003) is a novel tells about Shauzia, Parvana's best friend, who has fled to Afghanistan and now has to survive on her own on the streets of Peshawar, Pakistan. Her dog as only her friend is named Jasper. She must struggle for food, begging for money and looking for a safe place to sleep every night. Lavender field and Eiffel tower in Paris are her only destination for getting peace (Ellis, 2003:21). Life as a street kid for Shauzia is dangerous and terrifying because she should posses a strong will, brave spirit, and luck.

Afghanistan is a small landlocked country located within South Asia and Central Asia. Afghanistan has been at war for nearly forty years. The war was started in 1978 when the American-backed army was in hostile with a Soviet Union-backed army. In 1980 Soviet Union attack Afghanistan and the war broke out. The both side bombing each other and killing with modern weapons.

The second war appeared as civil war, when the various groups tried to become a leader in that country, after Soviet Union leaves from Afghanistan in 1989. The groups were very cruel. The appearance of the Taliban triggered more chaos. The Taliban was originally a term for a children whose parents were killed in a war against Uni soviet. In September 1996, Taliban forces finally dominated the capital of Kabul.

Millions of Afghans have fled their country, looking for safety in refugee camps and communities in Iran, Pakistan and other places. Life in the camps is very difficult. People frequently spend all their money simply trying to get out of the country. When they end up in a camp, they live without a steady supply of food, no clean water, no access to go to school, and no legal way to work to make their situation better.

This novel written by Deborah Ellis who was born on August, 7th 1960 in Cochrane, Ontario, Canada. She has been a professional author for almost thirty books for young people. She is best known for her Breadwinner series, which has been published in twenty five languages and has earned one million dollars in royalties to support Women in Afghanistan and International Street kids (Ellis, 2003:138-139).

It is necessary to do research to analyze the struggle of the main character to get her freedom. The main character dreams a comfortable life as common woman because the environment, the culture and the religion are under the Taliban's army. The Taliban regimes provides restrictions on women such as forbiding women to go to school, forbiding women to walk alone outdoors, and have to wear a burqa. Moreover, they are asked to live in muddy, crowded, refugee camp outside Peshawar, Widow's Compound where things are even worse (Ellis, 2003:18). The idea of the misery is the powerful narration in the story which is quite the representation of the problem in the novel.

The story of the novel is not merely seen as illustration but more importantly as misery of the oppressed woman. Thus, as Hall calls this aspect as shared concepts where language and representation for the members must distribute sets of concepts, images and ideas which enable them to think and feel about the world, and thus to interpret the world within same 'cultural codes' (Hall, 1997:4). Hall sparks an idea of representation could lead to oppressive act to woman through social hierarchy. Hence, the appropriate theory to analyze this problem is representattion by Stuart Hall. The theory will help to see the work of 
representation and by the additional concepts of Barbara in her book Gender Vertigo: American Families in Transition (1998) which criticizes the gender struggle in the novel Parvana Mud City.

There are some reasons why Parvana Mud City is taken as an object material for this research. First, Parvana Mud City is a novel written in cultural codes where gender oppression seems to be permissive. The second is to see the goal of the gender struggle in the novel Parvana Mud City and to show the limitation of achievement depicted by Parvana from the perspective of the author.

\section{RESEARCH METHODOLOGY}

Processing and analysing data need several steps. First is the main source data from the novel Parvana Mud City. It is important to read many time to get understanding about the whole parts of the story, exactly about the problem gender struggle in the novel.

Moreover, when the problem have found, it starts to do the data processing by collecting and classifying the data as well as the sentences or quotations from the source data related to the theory. The source data are taken from Mud Cityto dismantle the problem in the novel. The activity is briefly continued to a routine close-reading to the theoritical criticism, any other researcher, article that related to the problem.

Henceforth, analyzing the data are from the collected and categorized data. The further step is to operate them within the theoretical concepts. The analysis done in this method of course is based on the research question made before. The three questions mentioned in the first chapter are processed using the theory of representation and gender. The sequence of how theory and data are operated could give legitimacy to the rigid analysis of the problem discussed.

\section{RESULTS AND DISCUSSION}

The discursive practices are seen as motivating factor to lead person to do particular action in accordance with cultural code. Thus representation is used to unveil the cultural code within the novel such as militarism, patriarchal and cultural oppression. The cultural codes within the novel thus help to locate the position of each character with the shared cultural codes such as Veera who agrees with the oppression, Shauzia who opposes the cultural codes, and Parvana who gives alternatives to the cultural codes. The later position of the cultural code then determine the position of the main character and give illustration and strong motivation to rebel against the cultural code. Those three aspects help to generate the gender performativity in Shauzia and other characters through three different arrows, and they are the level of individual, interactional and institutional. The individual is the level of certain character accepting or rejecting the shared cultural codes, while the interactional is the level of particular character addressing the other character both men and women. The institutional concept help the idea of the strong imperative codes to be exercised to all characters as compulsory codes such as military system, patriarchal system and cultural system.

The representation in 1989-1996 is derived from the previous analysis. It represents the gender struggle to identify the discursive approach use in the story. Hence the analysis help to determine the condition of the social conflict during 1989-1996. In this analysis, it only uses the discursive approach. Hall stated that it will be nothing to discuss without a 
discourse because discourse always tells about something true and related to the historical context. Well, to know about the representation of gender struggle in Parvana Mud City, it only can be analyzed from the several discourses constructed in the novel by the author. In addition the previous analysis of gender as social sturcture by Risman (1999; 2004) tells about how gender as social structure becomes the source of inequality in a society. Relating to the condition of Afghan's women in the year 1966, their gender roles have been discriminated and they should struggle to get their rights because of the social structure from Taliban. So, they should struggle to get her rights with any kinds way.

The critical position of the author for the women condition in the novel weighs more into west perspective. Through the gender condition in Afghanistan society and the contextual backgrond, the writer tells her critical position for the condition of Afghanistan women and girls under the Taliban regime, to answer this question, it focuses more on the way how the author decides to agree or not toward that condition. Furthermore, to know either she agrees or not toward the condition, the researcher explores the content of the novel because the author shows many struggles experinced by the main characters through the novel. The three arrows help to understand the critical position as women should escape from the oppressive cultural code and fly to Europe, Paris. Next, the critical position is not to organize the massive act because some people are desperate to think of the punishment when they escape. Finally, writer wants to construct that ideal dream of getting freedom is only Paris because women are respected and equal as citizen. They are free from military, patriarchal and cultural perspective to dominate their rights as human.

Hall describes language is the privileged medium in which people 'make sense' of things, in which meaning is produced and exchanged and can only be shared through common access to language. Thus language is central to meaning and culture and has always been regarded as the key repository of cultural values and meanings (Hall, 1997:1) and in this research the cultural values becomes dominant code to determine social attitude.

The cultural codes share social determinant value which means the people in Afghanistan should follow certain conduct. Women in Afghanistan are less respected than men, this cultural code is depicted through the use of boy's clothing for women, free labor, and submissive act during the hard time. Thus, the woman imitates man more or to be more like man if they want to have better public access. The following analysis should began from Shauzia's perspective since she is the heroine of the story to confront her rights as human not for woman. The dominating cultural codes are challenged through many acts since she was in the widows camp.

Shauzia, fourteen years old girl, wishes of seeing new life by making a way to France, but it is difficult to harmonize that dream with the terrible conditions in the Afghan refugee camp where she lives. Worsened the situation is the camp leader, Mrs. Weera, who treats Shauzia as a servant because she needs someone to do the chores for her. She commands Shauzia for dressing like a boy, as her friend Parvana did, to get money to buy a ticket.

"Maybe I should have kept my hair short like a boy's instead of letting it grow back. That was Mrs. Weera's idea. Mrs. Weera orders me around, has dumb ideas, and won't even get me a decent pair of sandals. Look at these!" She took off a sandal and showed it to Jasper, who kept his eyes closed. The sandal was barely held together by bits of string (Mud City:9) 
The descriptions "Maybe I should have kept my hair short like a boy's instead of letting it grow back. That was Mrs. Weera's idea. Mrs. Weera orders me around, has dumb ideas, and won't even get me a decent pair of sandals." (Ellis, 2003:9) has shown that the society demands woman more. In this situation, the leader, MrsWeera, has more power to determine the life of the follower or the woman refugee in widows compound. However, Shauzia journey comes further with survival because she is forced to beg and take garbage, and eventually ending in prison. This happens because as woman she is regarded as non productive being and her work should not be praised. Everything does not work well for Shauzia. She asks Ms. Weera to make money, but she hears that she has to stay in the camp for the rest of her life. Shauzia is not happy with this, so she would leave the camp and find a way to make her own money.

She took a deep breath and headed to the nearest shop, a bookstall. "Give me a job!" she demanded of the man behind the stack of books. She was quickly ordered out of that shop, and away from the four other shops she went to...Shauzia and Jasper squeezed themselves into an alcove between shops. She could tell from the smell that they were sharing the space with decomposing fruit and other garbage, but at least they were out of the way of people, cars and shadows (Mud City:22)

From the statement "Give me a job!" she demanded of the man behind the stack of books. She was quickly ordered out of that shop, and away from the four other shops she went to... Shauzia and Jasper squeezed themselves into an alcove between shops" (Ellis, 2003:22), the idea of working is never meant for woman but man. Thus, many women should only work within the domestic area. Next, Shauzia meets a clear salvation by well-meaning American families to give her hope again in the middle of her survival. However, the American woman, Barbara treats her out of pity not humanity. Thus hierarchy between them says that Shauzia has no right to be with her, and she must obey her.

"I'd like to take the boys swimming this afternoon," Barbara told Shauzia when they were doing the lunch dishes together. "We go to the American Club. I wish I could take you, but it's only for ex-patriots. You know, foreigners? Would you be all right here on your own for a few hours?'Shauzia found the question funny. After all, she had been looking after herself for a long time (Mud City:53).

The statement "We go to the American Club. I wish I could take you, but it's only for ex-patriots. You know, foreigners? Would you be all right here on your own for a few hours?"Shauzia found the question funny. After all, she had been looking after herself for a long time" (Ellis, 2003:53) expresses the sense of politeness but at the same she knows that the hierarchy is playing on the conversation. She is actually never been invited to come along with them. This brings back the portrait of a devastating portrait of life in refugee, where so many children around the world are trapped, partly for their entire lives.

The analysis tells the cultural codes served for Shauzia is to pretend herself as a boy is good because boy has more rights than woman, Secondly woman has no right in public sector such as job and work outside, and the third other benevolence comes from pity not equality. 
The following analysis will explain better about the social determinant value applied in the novel.

Shauzia escapes from the widow compound and she arrives in a city and looks for job so she could support herself and her dog, Jasper but she always finds difficulty to be successful even outside of the camp. The city seems not friendly for a girl though she dresses her self as a boy already. In this part the discussion reveals the oppression happens on Shauziagiving strong argument how oppression could happen on her, not only individual, but also interactional and even more institutional.

"I don't need a few days to think about it," Shauzia said coldly, hoping she sounded braver than she felt. "I'm leaving tomorrow, and I'm going to find a great job and become rich, and go to France, and never come back here again!" "Very well," Mrs. Weera said quietly. "We'll have a farewell party for you tonight. "With that, she walked away (Mud City:14).

Shauzia dreams about living forever with the American family because she knows American also and she fantasizes about them taking her to the land of her dream, France. However, France becomes important in the story because it does not only give the imagination of freedom which is longed for by Shauzia but also because it generates the story to contrast the different value. It is the value of being Afghan Women and European Women.

\section{CONCLUSION}

The model of representation struggle appears in the novel is the idea where the cultural codes play significant role in determining Shauzia's life. The strong point is where Shauzia needs to performs herself as a boy to have more public access in her most desperate times. The problem of not knowing how to escape from widows compound has underlined on how the women, and children should be treated. Widow as name of fatherless or husbandless family create a persona of how social construction should place woman even in the moment of war. Shauzia's action to disguise herself as a boy telling how the hierarchy of women and men played in Afghan society.

The gender condition sets up in the midst of military, where men is the only gender practical for the military interest. This institutional oppression is compatible with the idea of turning herself into a boy functions as individual oppression. The two oppressions, institutional and personal, build strong dilemmas in Shauzia where she compares herself to the west and east value on how women should be treated. The the third oppression, the interactional oppression plays on the patriarchy and military values become the dominant social structure oppressions preventing her desire to claim her rights to go to France.

The critical position of the author is to promote how severe the life of the east contrasted to the west based on childhood illustration in Afghan setting. The idea of west where the rights of becoming more civilized, and respect the women liberty are essential for the every human to develop. 


\section{BIBLIOGRAPHY}

Ellis, D. 2003. Mud City. Berkeley: Groundwood Books House of Anansi Press.

Ellis, D. 2003. Three Wishes: Palestinian and Israeli Children Speak. Toronto: Groundwood Books, 2004. Print

Hall, S. 1997. Representation: Cultural Representation and Signfying Practices. London: Sage Publication.

Risman, J.B. 1999. Gender Vertigo: American Families In Transition. United States: Yale University Press.

Risman, J.B. 2004. "Gender as Social Structure: Theory Werstling with Activism”. in Gender and Society, 18(4):429—450. 